\title{
Mapping the Literature on Sustainability Reporting: A Bibliometric Analysis Grounded in Scopus and Web of Science Core Collection
}

\author{
By Oleh Pasko ${ }^{1}$, Fuli Chen ${ }^{2}$, Alvina Oriekhova ${ }^{3}$, Alina Brychko ${ }^{4}$, Iryna Shalyhina ${ }^{5}$
}

\begin{abstract}
Sustainability reporting has become an increasingly common practice among companies around the globe as around $90 \%$ of the world's 250 largest companies from Fortune 500 prepare and publish its sustainability reporting. Aiming to help researchers to grasp the intellectual landscape of global research on sustainable reporting, we conducted a bibliometric analysis using CiteSpace software by applying evaluative and relational techniques to 928 articles published in 480 different journals in Scopus and 698 articles published in 374 different journals in Web of Science Core Collection from 1981 to 2020. Our findings indicate that the number of articles published in the field has increased rapidly, especially since 2009. We identified the leading countries (the United States, Australia, the United Kingdom, Germany, Spain, Canada, the Netherlands and Italy), the most prolific journals (Journal of Cleaner Production, Business Strategy and the Environment, Journal of Business Ethics), main journals categories (Business, Economics, Management and Finance, Environmental and Ecology and Science, Technology and Engineering), and the major research directions in the near future (sustainability reporting, corporate social responsibility, sustainable development, disclosure). From our findings we infer that the sustainability reporting research has just recently (2013-2019) gained traction in the literature. Moreover, our findings testify that a kind of bifurcation point has occurred is 2011 that manifests the maturity of the field of sustainability reporting. All this provides the reader with a high-view look at sustainable reporting as these quantitative findings complementing qualitative and providing valuable insights into the field.
\end{abstract}

Keywords: Sustainability Reporting, Bibliometric, Citespace, Scopus, Web of Science Core Collection.

\section{Introduction}

Sustainability reporting has become an increasingly common practice among companies around the globe while the latter try to match the expectations and counter the criticism and pressures from stakeholders who demand an ever greater level of companies' accountability about their social and environmental impact (Boiral, 2013). The latest available global statistical data testifies to the trend as $75 \%$ (compared to $18 \%$ in 2002) of

| $1 \mathrm{PhD}$, Assoc. Prof., Department of Accounting and Taxation, Faculty of Economics and Management, Sumy National Agrarian University, 160, Herasyma Kondratiieva str., 40021 Sumy, Ukraine

${ }^{2}$ Lecturer, Department of Publicity Office, Henan Institute of Science and Technology, Eastern HuaLan Avenue, 453003 Xinxiang, China; PhD student at Sumy National Agrarian University, Sumy, Ukraine

${ }^{3}$ D.Sc., Full Prof., Department of Accounting and Taxation, Faculty of Economics and Management, Sumy National Agrarian University, 160, Herasyma Kondratiieva str., 40021 Sumy, Ukraine

${ }^{4} \mathrm{PhD}$, Assoc. Prof., Department of Public Management and Administration, Faculty of Economics and

Management, Sumy National Agrarian University, 160, Herasyma Kondratiieva str., 40021 Sumy, Ukraine

${ }^{5} \mathrm{PhD}$, Assoc. Prof., Department of Finance, Banking and Insurance, Faculty of Economics and Management,

Sumy National Agrarian University, 160, Herasyma Kondratiieva str., 40021 Sumy, Ukraine 
N100 companies (the top 100 companies by revenue in each of the 49 countries researched) and 93\% (compared to 45\% in 2002) of G250 companies (the world's 250 largest companies by revenue based on the Fortune 500 ranking of 2016) prepare and publish its sustainability reporting (KPMG, 2017, p. 9).

The research in sustainability reporting is now vast area covering the preparation of the very report including among others frameworks of SR (Dumay, 2019; Hahn \& Lülfs, 2014), voluntary vs. mandatory reporting (La Torre et al., 2020; Tjahjadi et al., 2020), stakeholders engagement (Bepari \& Mollik, 2016; Herremans et al., 2016; Rhianon Edgley et al., 2010), materiality (Canning et al., 2019; Mio et al., 2020; Torelli et al., 2020), quality of SR (Daub, 2007; Michelon et al., 2015; van Staden \& Hooks, 2007) as well as SR assurance which is manifested in such topics as accounting vs. non-accountants assurance providers (Farooq \& de Villiers, 2017, 2019a, 2019b), assurance report content and quality (Hummel et al., 2019; Rossi \& Tarquinio, 2017). This research areas constantly (1) produce a tangible amount of new publications and (2) gives new shoots in terms of the emergence of new branches of research and that in turn engenders the emergence of new studies that seek to capture the ever-growing field using the bibliometrics techniques into a digestible picture.

The bibliometric analysis is a very helpful utilitarian tool for researchers, journal editors and reviewers, as it assists in the transformation of qualitative information into quantitative and that in turn leads to the ability to draw conclusions pertaining "the magnitude of papers that may exist on a specific line of research or topic" (Baraibar-Diez et al., 2020). The bibliometric analysis provides a high-view look at the research areas that have attracted attention on a certain topic, paradigms or concepts, besides today "studies with data have more relevance than those subjective analyses" (Fabregat-Aibar et al., 2019, p. 2). The preceding studies employing bibliometrics have classified its techniques into three categories: review techniques, evaluative techniques, and relational techniques (BaraibarDiez et al., 2020; Fabregat-Aibar et al., 2019). This paper utilizes the last two mentioned, namely evaluative techniques and relational techniques.

Notwithstanding the prominent position, the topic of sustainability reporting enjoins in the literature the dearth of a bibliometric approach to the subject matter is palpable in the field. We tried to find the bibliometric or systematic reviews papers devoted to the sustainability reporting per se and our search resulted in only a few of them (Dienes et al., 2016; Hahn \& Kühnen, 2013) but the latest period covered was mid-2015 (Dienes et al., 2016). Even without considering the non-identical methodological and technical approaches used in those articles as contrasted to ours, the period of 5 years by the standards of the modern research world is a significant period warranting fresh research covering the subject matter up to present day. Although we came across some freshminted bibliometric research closely related to the topic at hand (Araújo et al., 2020; Fusco \& Ricci, 2019; Gulluscio et al., 2020; Pizzi et al., 2020; Rodrigues \& Mendes, 2018), at close examination all those papers targeting domain that does not fit perfectly to sustainability reporting research.

In the light of the foregoing, the paper aims to provide researchers with a quantified and visualized snapshot of the domain of sustainability reporting covering all the publication available in the leading databases Scopus and Web of Science Core Collection from 1981 up to 2020. Our main research tool is CiteSpace, freely available Java application for 
visualizing and analyzing trends and patterns in the scientific literature. Our study has several specific goals enabling reaching the overall aim, namely: (1) to introduce the readers to the field and present a high-view picture on global publications related to sustainability reporting in almost last 40 years; (2) to identify the prime contributors in the domain, together with the leading countries, journals, authors, articles, topics; and (3) to identify the bursting keywords during the last 40 years and reveal based on the latest bursting topics future research directions. To the best of our knowledge, this paper is the first study using CiteSpace fully devoted to sustainability reporting and covering almost 40 years of research in the area.

The remainder of the paper is organized as follows. First, the overall method of the study, including research design, data source of analysis and research tools at use is demonstrated in the next section. The third section reveals the main finding of the paper and the paper concludes with discussions and conclusions.

\section{Methods}

The bibliometric method, utilized in this study, takes advantages of contemporary technologies in computer engineering, huge strides in database management and statistics achieved in the last decade. The method of bibliometric analysis is to make statistics of numerous scientific publications in a certain research field, and reveal the history, current situation and trend of the research field through statistical tables and statistical images. At the same time, this method can also mark the evolution of the research field and provide references for researchers in this field. Eugene Garfield who stood behind Science Citation Index in the 1950s (now morphed to be a part of WoS CC) was one of the first who understood the importance of citations and went on to established database of it (C. Chen, 2018). At the time citation were employed with the goal similar to ours in this study to "help for researchers to search the literature more effectively" (Mingers \& Leydesdorff, 2015, p. 2) and "also enabled unfamiliar authors to be discovered" (Mingers \& Leydesdorff, 2015, p. 2). After it was confirmed that Garfield's statistical analysis keywords predicted suggested the future science directions (Barton et al., 1990), bibliometric analysis by keywords to analyze research trends has proved to be effective in recent years (D. Chen et al., 2016).

\subsection{Research Design}

The method of this research can be summarized into 5 steps (figure 1). The first step was planning through reading related references, analyze which items are meant to measure, and initially determine the items that need bibliometrics. The second step was a preliminary search. This step aimed at determining according to research needs, the search keywords through search and also to explore feasible data presentation methods and discover possible problems among them. At this stage very important task was presearching, selecting appropriate software and measurement methods, determine how to present the results of bibliometric analysis.

After the first two stages prepared the ground, we initiate the main search - our third step. The main activity at this stage was to perform a search, select documents that meet the requirements, and download the corresponding bibliographic information. The fourth step 
is data preprocessing. At this stage, the downloaded bibliographic information is converted into a usable format, and appropriate sorting and inspection are performed to eliminate occasional format errors in format conversion and downloading. The fifth step is to reveal and to present the results and analysis, display the results of bibliometrics, and select suitable parameters through repeated attempts to display the results.

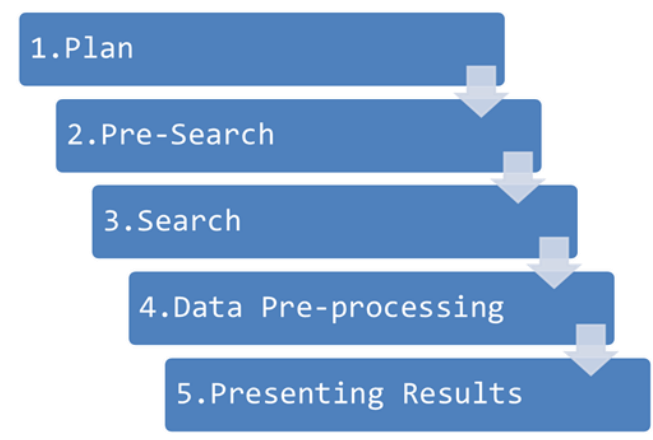

Figure 1. Schematic diagram of the research method

\subsection{Data collection}

The gathering of bibliometric data implies the selection of the database(s), to clarify and purify the bibliographic data and at least to refine it. We decided to make use of two world-leading research databases that adhere to rigorous standards in content selection and maintenance - Scopus (run by Elsevier) and Web of Science Core Collection (run by Clarivate) (Gusenbauer, 2019; Rousseau et al., 2018). Although Google Scholar according to some studies is believed to be the largest database (Gusenbauer, 2019) its approach to data curation is in our opinion is questionable and hardly make it a reliable source for analysis.

Sustainability reporting is a multi-disciplinary research subject of economy, management, environment, science and technology. To make the data sources more comprehensive, Scopus and Web of Science Core Collection (hereinafter referred to as WoS) are selected for the research data of this article. Scopus is currently the world's largest research abstract and citation database, containing 24,600 journals from 5000 publishers (Elsevier, 2020). WoS is a reliable, high-quality authoritative database generally recognized by scientific researchers. Its core collection is an index of high-quality scientific research articles selected by editors. To make the search results more concentrated, after pre-searching, we chose to use "sustainab* report*" in the title as the search condition and finally got 928 effective search records in Scopus and 698 effective search records in WoS. After exporting the search results into text format and Excel format respectively, CiteSpace and Excel are used to analyze, make tables and draw knowledge graphs.

The data retrieval time is October 8, 2020. The exact string used to search in Scopus is "TITLE (sustainab* AND report*) AND DOCTYPE (ar) AND PUBYEAR> 1959 AND PUBYEAR <2020", and the search results are 931 (Table 1). A total of 3 data formats have problems and were deleted. The final search formula for WoS database is "TI= sustainab* and TI=report* Refined by: DOCUMENT TYPES: (ARTICLE) Databases= WOS Timespan=1950-2019 Search language=Auto", and the search results are 698 . 
Table 1. The search formula used

\begin{tabular}{|l|l|l|}
\hline & Scopus & Web of Science Core Collection \\
\hline $\begin{array}{l}\text { search } \\
\text { formula }\end{array}$ & $\begin{array}{l}\text { "TITLE (sustainab* AND report*) AND } \\
\text { DOCTYPE (ar) AND PUBYEAR }> \\
\text { 1959 AND PUBYEAR <2020" }\end{array}$ & $\begin{array}{l}\text { "TI= sustainab* and TI=report* Refined by: } \\
\text { DOCUMENT TYPES: (ARTICLE) Databases= } \\
\text { WOS Timespan=1950-2019 Search language=Auto" }\end{array}$ \\
\hline $\begin{array}{l}\text { The data of } \\
\text { retrieval }\end{array}$ & October 8, 2020 & October 8, 2020 \\
\hline $\begin{array}{l}\text { Results of } \\
\text { the search }\end{array}$ & 931 articles & 698 articles \\
\hline
\end{tabular}

Some articles lacking DOI and publication year were supplemented after the source was retrieved.

\subsection{Research tools}

The tools used in this article include CiteSpace 5.7.R1 (64bit), which was devised by C.M. Chen at Drexel University in 2004 (Chen, 2004) and since then is widely used. As the axillary tools, we also use MS Excel 2010, and Stata 16.0. CiteSpace is a popular bibliometric tool that can draw knowledge graphs through bibliometric methods to show the relationship network between the various attributes of the literature (de Bellis, 2014; Gao et al., 2020). It can also output statistical tables corresponding to the graphs. Excel is used to filter and count data, and to make tables. We resort to Stata's pvenn software package to draw a Venn diagram to show the number and proportion of documents in the two databases. So in a nutshell, the Venn diagram was drawn using Stata 16.0 and the software package pvenn, the histogram was drawn using MS Excel 2010, the cooccurrence maps are drawn using CiteSpace 5.7.R1. The data in the table comes from the statistical results of CiteSpace. Some of the data in the tables are collected manually and are indicated below the tables. To make our research more replicable we adduce the search string in CiteSpace we used for specific data throughout the paper from here on.

\section{Results}

\subsection{Databases distribution}

The fact that we make use of two databases gives us a much larger sample compared to the hypothetical situation when we stopped our choice on only one of the databases (Figure 2).

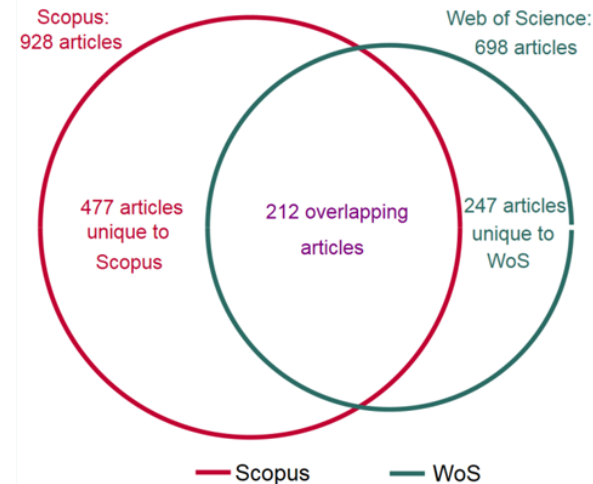

Figure 2. Database distribution of relevant articles 
Figure 2 shows the number of articles in the Scopus and WoS databases with "sustainability report" in the title, and the number of overlapping articles. The number of articles in Scopus $(n=928)$ is greater than that in WoS $(n=698)$. There are a total of 1,626 articles in the search results, of which 451 are repeated in the Scopus and WoS databases. Although there are many crossovers, many articles are in only one database: Scopus has 477 of those articles and WoS - 105 articles. Therefore, using both Scopus and WoS databases can make our research results more comprehensive. Compared with using two databases at the same time, if the Scopus database is not used, the parameters of the research would have been reduced by $29.3 \%$, and if the WoS database is not used - by $15.2 \%$.

\subsection{Output overview}

It is worth noting three significant years: the first appearance of the publication related to the subject matter, the year when the number of publications exceeded 10 , and the year when the number of annual publications exceeded 100. In the search results of this article, the sustainability report-related articles included in the Scopus and WoS databases first appeared in 1981. Since 2004, the number of related articles published per year has exceeded 10, and since then, every year the number of publications has increased steadily. Beginning in 2015, the number of articles per year has exceeded 100.

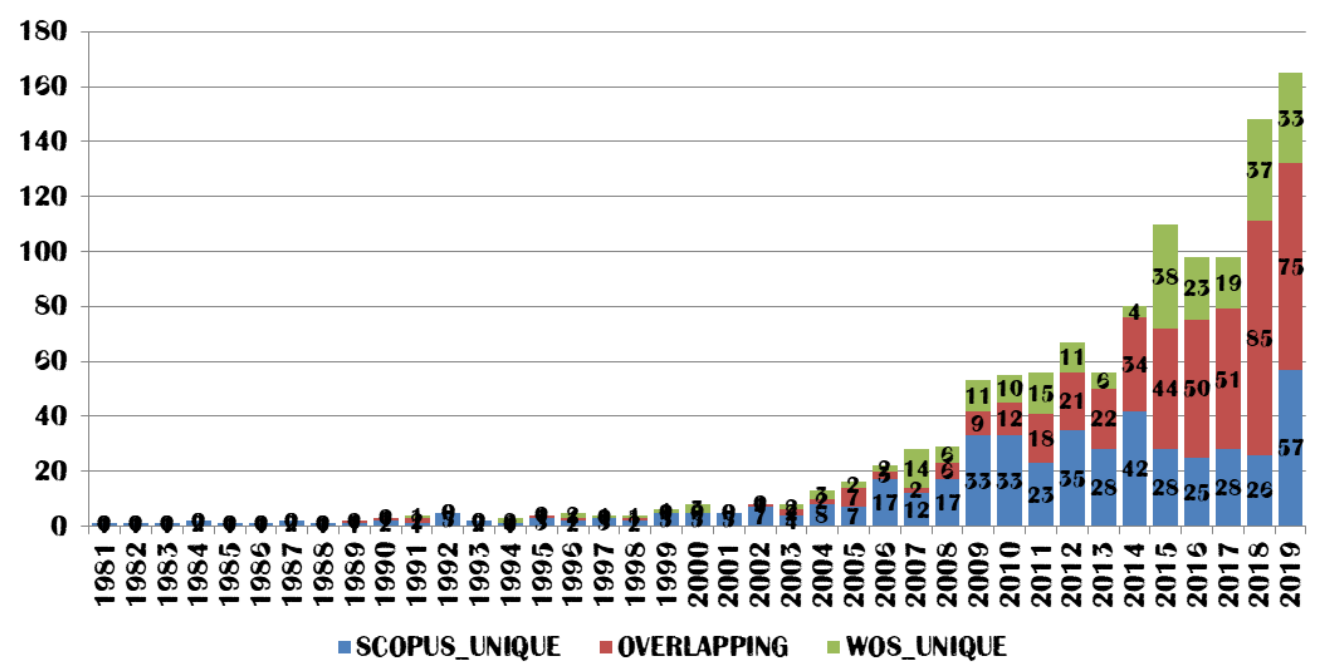

Figure 3. Number of publications

In bibliometrics the networks connection are analysed through citations, therefore it is imperative to overview citation count (Figure 3). The number of citations can be divided into three stages based on 2000 and 2015. Before 2000, only articles published in 1991, 1995, and 1997 had a large number of citations. Important documents appeared in these three years. From 2001 to 2015, the number of citations increased rapidly and reached a peak in 2015. The number of citations of articles published after 2015 has gradually decreased. We want to issue a warning at this point for you to take those data with caution because the reason for it is that these articles were published later, and it takes longer to reach more citations. 


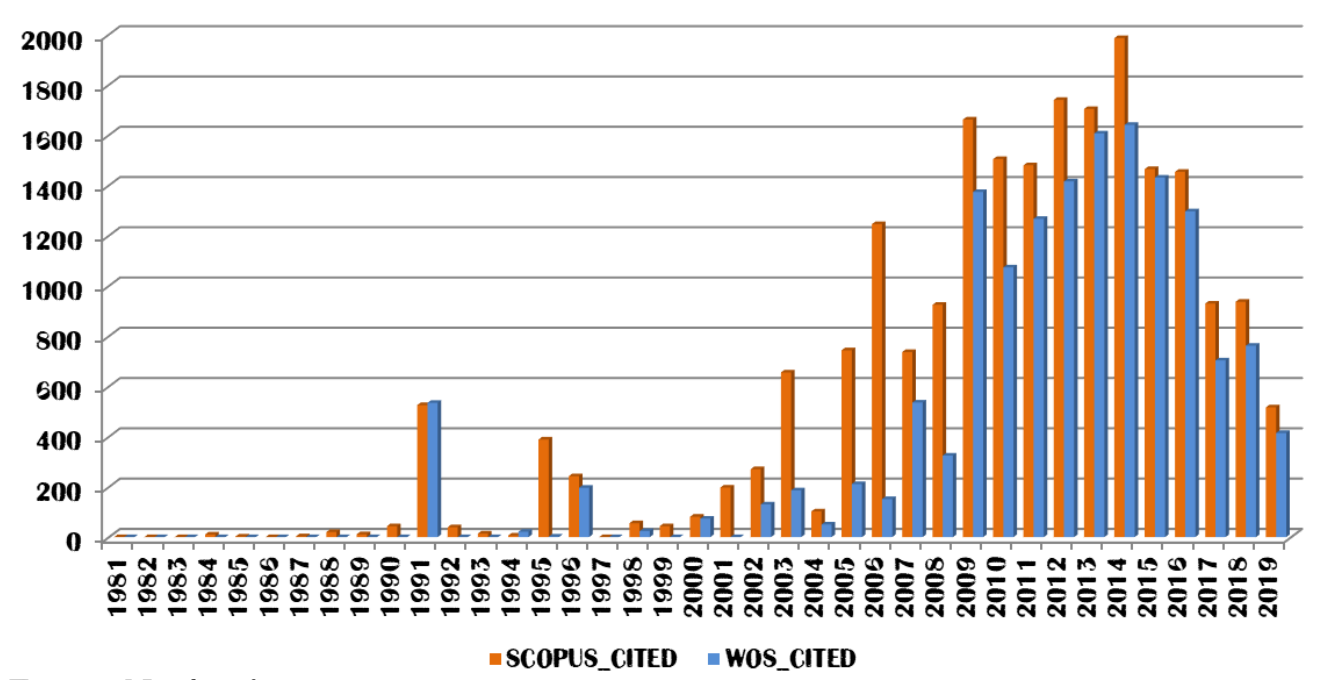

Figure 4: Number of citations

\subsection{Country distribution}

Scopus and WoS include different journals and articles. Statistics on the countries where the authors are located can be used to understand which countries scholars have made more contributions to the sustainability report research. To make our research more replicable we adduce the search string we used. We made the following input parameters in CiteSpace: (1) 1 years per interval from 1981 to 2019; (2) term source = title/abstract/author/keywords/keywords plus; (3) node type = country; (4) pruning = none; (5) selection criteria is g-index scale factor $\mathrm{k}=25$; (6) look back years $=8$; (7) link retaining factor $=3$.

Figures 5 and 6 are schematic diagrams of statistics by country in the Scopus and WoS databases, respectively. The UK data in the Web of Science database is divided into England, Scotland, Wales, Northern Ireland, etc., and we merge them into the United Kingdom. For easy viewing, we adjusted the positions of nodes representing each country according to the size of the area. The larger the area of the node, the more the number of articles published in the country. The outer circle of the node represents betweenness centrality. The thicker the outer circle, the stronger the importance of the relevant literature published in the country.

In Figure 5 and Figure 6, we can see that in the Scopus database, the United States, Australia, the United Kingdom, Germany, and Spain are the top five countries with the most publications. In the WoS database, the United States, the United Kingdom, Australia, Spain and Germany are the countries with the most publications. 


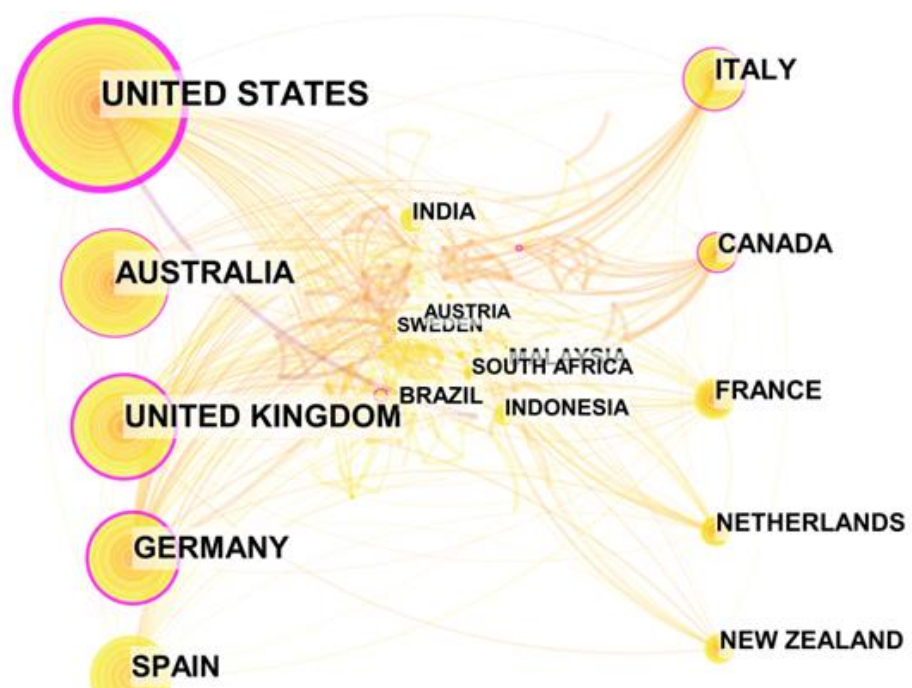

Figure 5. Top 10 countries with the most articles (Scopus)

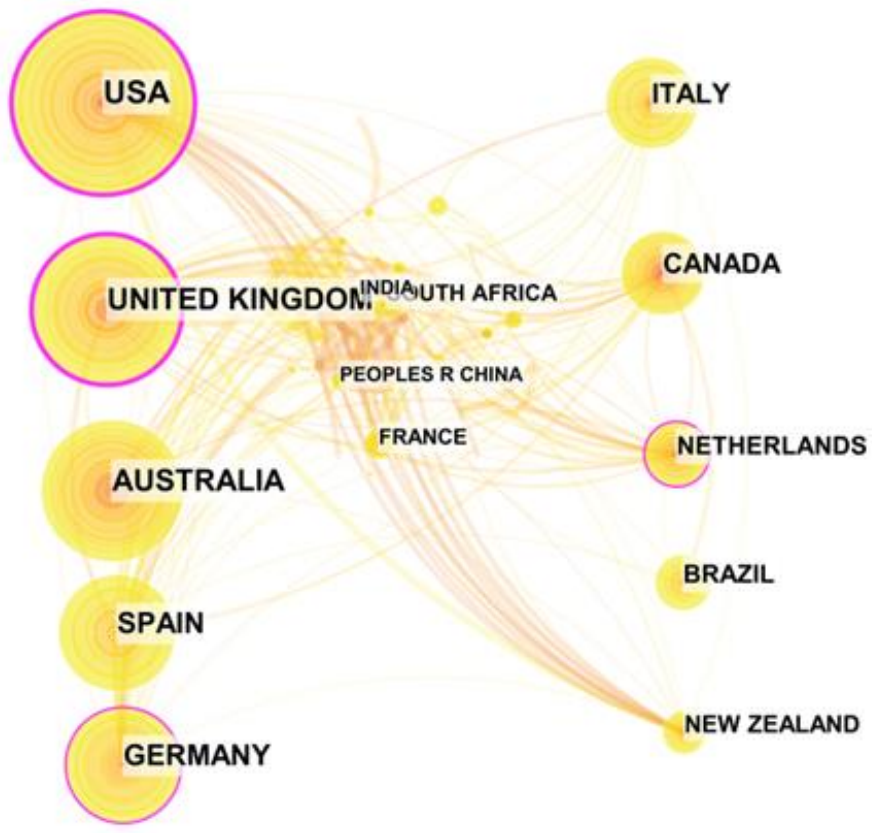

Figure 6. Top 10 countries with the most articles (Web of Science Core Collection)

Table 2 shows the betweenness centrality and ranking of the top 5 countries in Figure 5 and Figure 6. It can be seen that in the Scopus database, the top five betweenness centrality rankings are the United States, Germany, the United Kingdom, Canada, and Australia. In the WoS database, the top 5 are the United Kingdom, the United States, Germany, the Netherlands and Italy. 
Table 1. Top 10 countries with the most articles

\begin{tabular}{|c|c|l|c|c|c|c|c|c|c|}
\hline \multicolumn{3}{|c|}{ Scopus } & \multicolumn{5}{c|}{ Web of Science Core Collection } \\
\hline \# & Freq & Country & Centrality & $\begin{array}{c}\text { Rank } \\
\text { Centrality) }\end{array}$ & $\#$ & Freq & Country & Centrality & $\begin{array}{c}\text { Rank } \\
\text { (Centrality) }\end{array}$ \\
\hline 1 & 151 & United States & 0.75 & 1 & 1 & 103 & USA & 0.28 & 2 \\
\hline 2 & 99 & Australia & 0.13 & 5 & 2 & 80 & United Kingdom & 0.34 & 1 \\
\hline 3 & 96 & United Kingdom & 0.32 & 3 & 3 & 78 & Australia & 0.02 & 8 \\
\hline 4 & 80 & Germany & 0.38 & 2 & 4 & 64 & Spain & 0.02 & 8 \\
\hline 5 & 76 & Spain & 0.07 & 7 & 5 & 63 & Germany & 0.14 & 3 \\
\hline 6 & 62 & Italy & 0.1 & 6 & 6 & 53 & Italy & 0.06 & 5 \\
\hline 7 & 48 & Canada & 0.15 & 4 & 7 & 51 & Canada & 0.05 & 7 \\
\hline 8 & 44 & France & 0.05 & 8 & 8 & 38 & Netherlands & 0.13 & 4 \\
\hline 9 & 38 & Netherlands & 0.04 & 9 & 9 & 35 & Brazil & 0 & 10 \\
\hline 10 & 34 & New Zealand & 0.01 & 10 & 10 & 29 & New Zealand & 0.06 & 5 \\
\hline
\end{tabular}

\subsection{Periodicals}

Table 3 lists the 10 most cited journals in the relevant literature of the "Sustainability Report". Because some references may overlap, the number of references from the two databases is not merged. Table 2 shows the citations of Scopus and WoS databases respectively sorted separately as well as the JCR and SJR indicators. It can be seen that the sustainability report research has been published in journals with greater influence.

Table 3. The most cited journals and their impact factors

\begin{tabular}{|c|c|c|c|c|c|c|}
\hline \multicolumn{7}{|c|}{ Scopus } \\
\hline \# & Journal title & $I S S N$ & $\begin{array}{l}\text { CiteScore } \\
2019\end{array}$ & $\begin{array}{l}\text { SJR } \\
2019\end{array}$ & Articles & Citations \\
\hline 1 & Journal of Cleaner Production & $0959-6526$ & 10.9 & 1.89 & 44 & 2457 \\
\hline 2 & Business Strategy and the Environment & $0964-4733$ & 8.4 & 1.83 & 33 & 2699 \\
\hline 3 & Sustainability (Switzerland) & 2071-1050 & 3.2 & 0.58 & 33 & 426 \\
\hline 4 & Journal of Business Ethics & $0167-4544$ & 7.0 & 1.97 & 26 & 1630 \\
\hline 5 & $\begin{array}{l}\text { International Journal of Sustainability in } \\
\text { Higher Education }\end{array}$ & $1467-6370$ & 3.2 & 0.64 & 24 & 244 \\
\hline 6 & $\begin{array}{l}\text { Corporate Social Responsibility and } \\
\text { Environmental Management }\end{array}$ & $1535-3958$ & 5.9 & 0.97 & 23 & 1071 \\
\hline 7 & $\begin{array}{l}\text { Accounting, Auditing and } \\
\text { Accountability Journal }\end{array}$ & $0951-3574$ & 4.9 & 1.46 & 16 & 1419 \\
\hline 8 & Social Responsibility Journal & $1747-1117$ & 2.5 & 0.43 & 14 & 199 \\
\hline 9 & $\begin{array}{l}\text { Sustainability Accounting, } \\
\text { Management and Policy Journal }\end{array}$ & $2040-8021$ & 3.8 & 0.67 & 12 & 362 \\
\hline 10 & Sustainable Development & 0968-0802 & 4.9 & 1 & 10 & 196 \\
\hline \multicolumn{7}{|c|}{ Web of Science Core Collection } \\
\hline \# & Joumal title & ISSN & CiteScore 2019 & SJR 2019 & Articles & Citations \\
\hline 1 & Journal of Cleaner Production & $0959-6526$ & 10.9 & 1.89 & 47 & 2681 \\
\hline 2 & Sustainability & $2071-1050$ & 3.2 & 0.58 & 36 & 307 \\
\hline 3 & Journal of Business Ethics & $0167-4544$ & 7.0 & 1.97 & 28 & 1775 \\
\hline 4 & Business Strategy and the Environment & $0964-4733$ & 8.4 & 1.83 & 26 & 1269 \\
\hline 5 & $\begin{array}{l}\text { Corporate Social Responsibility and } \\
\text { Environmental Management }\end{array}$ & $1535-3958$ & 5.9 & 0.97 & 24 & 840 \\
\hline 6 & $\begin{array}{l}\text { Accounting, Auditing \& } \\
\text { Accountability Journal }\end{array}$ & $0951-3574$ & 4.9 & 1.46 & 14 & 589 \\
\hline 7 & $\begin{array}{l}\text { International Journal of } \\
\text { Sustainability in Higher Education }\end{array}$ & $1467-6370$ & 3.2 & 0.64 & 13 & 283 \\
\hline 8 & Sustainable Development & 0968-0802 & 4.9 & 1 & 10 & 168 \\
\hline 9 & Social Responsibility Journal & $1747-1117$ & 2.5 & 0.43 & 9 & 76 \\
\hline 10 & Meditari Accountancy Research & 2049-372X & 5.0 & 0.95 & 7 & 72 \\
\hline
\end{tabular}


In the Scopus database, 928 articles were published in 480 different journals. In the WoS database, 698 articles were published in 374 different journals.

The most cited journal (in absolute terms) in the study is the Journal of Cleaner Production, and the number of articles published in it is also the largest one. But if you count the citation per article, it (Journal of Cleaner Production) is inferior to Business Strategy and the Environment and Journal of Business Ethics. On average, each article in Journal of Cleaner Production is cited about 56 times in the Scopus database and about 57 times in the WoS database, whereas in "Business Strategy and the Environment", each article is cited about 82 times in the Scopus database and about 63 times in the WoS database and for Journal of Business Ethics the numbers are 63 in both databases.

\subsection{Authors}

Counting the search results, we can find that 393 authors are participating in 928 articles in the Scopus database, and 460 authors participating in 698 articles in the WoS database. Table 4 shows the top 10 authors with the largest number of articles, the organizations and countries they represent, the articles published and cited, and the $\mathrm{H}$ index of these authors. Interestingly enough, in two databases, only 3 of the top 10 authors have overlapped (Fernandez-Feijoo B. from Universidade de Vigo, Uyar A. from La Rochelle Business School, Boiral O. affiliated with Université Laval).

Table 4. Top 10 authors with the most published articles

\begin{tabular}{|c|c|c|c|c|c|c|c|c|}
\hline \multirow{3}{*}{$\begin{array}{l}\# \\
\mathbf{S c}\end{array}$} & \multirow{2}{*}{ Author } & \multirow{2}{*}{ Organization } & \multirow{2}{*}{ Country } & \multirow{2}{*}{\multicolumn{2}{|c|}{\begin{tabular}{|c|} 
Articles \\
SR* total \\
\end{tabular}}} & \multirow{2}{*}{\multicolumn{2}{|c|}{\begin{tabular}{|l|} 
Citations \\
SR* \\
total \\
\end{tabular}}} & \multirow{2}{*}{$H$-index } \\
\hline & & & & & & & & \\
\hline & \multicolumn{8}{|c|}{ Scopus } \\
\hline 1 & Amran A. & Universiti Sains Malaysia & Malaysia & 7 & 87 & 334 & 1384 & 21 \\
\hline 2 & James M.L. & California State University & United States & 6 & 20 & 28 & 46 & 4 \\
\hline 3 & Uyar A. & La Rochelle Business School & France & 6 & 53 & 93 & 709 & 14 \\
\hline 4 & Romero S. & Montclair State University & United States & 5 & 16 & 281 & 416 & 10 \\
\hline 5 & Boiral O. & Université Laval & Canada & 5 & 91 & 376 & 4117 & 34 \\
\hline 6 & Adams C.A. & La Trobe University & Australia & 5 & 50 & 677 & 3555 & 25 \\
\hline 7 & Fernandez-Feijoo B. & Universidade de Vigo & Spain & 5 & 20 & 270 & 439 & 9 \\
\hline 8 & Kaur A. & $\begin{array}{l}\text { University of South Australia } \\
\text { Business School }\end{array}$ & Australia & 5 & 9 & 53 & 61 & 4 \\
\hline 9 & Ruiz S. & University of Vigo & Spain & 4 & 10 & 194 & 304 & 7 \\
\hline 10 & Patten D.M. & Illinois State University & United States & 4 & 65 & 225 & 5944 & 32 \\
\hline \multicolumn{9}{|c|}{ Web of Science Core Collection } \\
\hline 1 & Fernandez-Feijoo B. & Universidade de Vigo & Spain & 7 & 20 & 272 & 439 & 9 \\
\hline 2 & Boiral O. & Université Laval & Canada & 7 & 91 & 349 & 4117 & 34 \\
\hline 3 & Rezaee Zabihollah & Univ Memphis & United States & 6 & 87 & 0 & 1527 & 21 \\
\hline 4 & Del Mar Alonso-Almeida M. & $\begin{array}{l}\text { Universidad Autónoma } \\
\text { de Madrid }\end{array}$ & Spain & 6 & 70 & 228 & 1851 & 23 \\
\hline 5 & Uyar A. & La Rochelle Business School & France & 5 & 53 & 72 & 709 & 14 \\
\hline 6 & Searcy C. & Ryerson University & Canada & 5 & 83 & 368 & 3658 & 29 \\
\hline 7 & Skouloudis A. & University of the Aegean & Greece & 4 & 42 & 21 & 589 & 16 \\
\hline 8 & Dittrick P & University of Texas at Austin & United States & 3 & 364 & 5 & 71 & 3 \\
\hline 9 & Karaman Abdullah S. & $\begin{array}{l}\text { American University of } \\
\text { the Middle East }\end{array}$ & Kuwait & 3 & 17 & 16 & 75 & 5 \\
\hline 10 & Kaur Amanpreet & University of South Africa & South Africa & 3 & 9 & 20 & 61 & 4 \\
\hline
\end{tabular}

* - Sustainability reporting related.

Data source: scopus.com. Visit time: October 25th, 2020. 


\subsection{Articles}

According to the data of Scopus and WoS, Table 5 lists the basic information of the top 10 articles ranked by the number of citations. The histogram shows the amount of usage each year. Because of the overlap between Scopus and WoS citation data, data from Google Scholar (searched at 2020.10.25) is used. Table 4 lists the article title, author(s), journal name, DOI, and the number of citations (Scopus, WoS, Google Scholar). Among the top 10 articles cited, Scopus contains all 10 articles, and only 4 articles are included in the WoS.

Table 5. Top 10 most cited articles

\begin{tabular}{|c|c|c|c|c|c|c|c|}
\hline$\#$ & Title & Author(s) & Journal & $D O I$ & 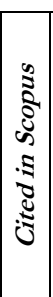 & 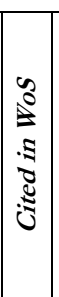 & 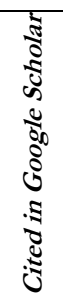 \\
\hline 1 & $\begin{array}{l}\text { The Sustainable Biosphere Initiative: } \\
\text { an ecological research agenda. A report } \\
\text { from the Ecological Society of America }\end{array}$ & $\begin{array}{l}\text { (Lubchenco et } \\
\text { al., 1991) } \\
\text { Lubchenco J. }\end{array}$ & Ecology & $10.2307 / 2937183$ & 497 & 534 & 1151 \\
\hline 2 & $\begin{array}{l}\text { Assurance on sustainability reports: } \\
\text { An international comparison }\end{array}$ & $\begin{array}{l}\text { (Simnett et al., } \\
\text { 2009) } \\
\text { Simnett R., } \\
\text { Vanstraelen A., } \\
\text { Chua W.F. } \\
\end{array}$ & $\begin{array}{l}\text { Accounting } \\
\text { Review }\end{array}$ & $\begin{array}{c}10.2308 / \text { accr. } 2009 \\
84.3 .937\end{array}$ & 472 & 434 & 977 \\
\hline 3 & $\begin{array}{l}\text { Environmental indicators: a systematic } \\
\text { approach to measuring and reporting on } \\
\text { environmental policy performance in } \\
\text { the context of sustainable development }\end{array}$ & $\begin{array}{l}\text { Hammond A., } \\
\text { Adriaanse A., } \\
\text { Rodenburg E., } \\
\text { Bryant D., } \\
\text { Woodward R. }\end{array}$ & $\begin{array}{l}\text { Fuel and Energy } \\
\text { Abstracts }\end{array}$ & $\begin{array}{l}10.1016 / 0140- \\
6701(95) 98081-2\end{array}$ & 383 & - & 1207 \\
\hline 4 & $\begin{array}{l}\text { W(h)ither Ecology? The Triple Bottom } \\
\text { Line, the Global Reporting Initiative, } \\
\text { and Corporate Sustainability Reporting }\end{array}$ & $\begin{array}{l}\text { (Milne \& Gray, } \\
\text { 2013) } \\
\text { Milne M.J., } \\
\text { Gray R. } \\
\end{array}$ & $\begin{array}{l}\text { Journal of Business } \\
\text { Ethics }\end{array}$ & $\begin{array}{c}10.1007 / \mathrm{s} 10551- \\
012-1543-8\end{array}$ & 358 & 326 & 825 \\
\hline 5 & $\begin{array}{l}\text { Determinants of sustainability reporting: } \\
\text { a review of results, trends, theory, and } \\
\text { opportunities in an expanding } \\
\text { field of research }\end{array}$ & $\begin{array}{l}\text { (Hahn \& } \\
\text { Kühnen, 2013) } \\
\text { Hahn, R; } \\
\text { Kuhnen, M }\end{array}$ & $\begin{array}{l}\text { Journal of cleaner } \\
\text { production }\end{array}$ & $\begin{array}{l}\text { 10.1016/j.jclepro. } \\
\text { 2013.07.005 }\end{array}$ & 349 & - & 963 \\
\hline 6 & $\begin{array}{l}\text { Sustainability, accountability and } \\
\text { corporate governance: Exploring } \\
\text { multinationals' reporting practices }\end{array}$ & $\begin{array}{l}\text { (Kolk, 2008) } \\
\text { Kolk A. }\end{array}$ & $\begin{array}{l}\text { Business Strategy and } \\
\text { the Environment }\end{array}$ & 10.1002/bse. 511 & 329 & - & 816 \\
\hline 7 & $\begin{array}{l}\text { Trends in sustainability reporting } \\
\text { by the fortune global } 250\end{array}$ & $\begin{array}{l}\text { (Kolk, 2003) } \\
\text { Kolk A. }\end{array}$ & $\begin{array}{l}\text { Business Strategy and } \\
\text { the Environment }\end{array}$ & 10.1002/bse. 370 & 293 & - & 811 \\
\hline 8 & $\begin{array}{l}\text { Social, environmental and sustainability } \\
\text { reporting and organisational value } \\
\text { creation?: Whose value? } \\
\text { Whose creation? }\end{array}$ & $\begin{array}{l}\text { (Gray, 2006) } \\
\text { Gray R. }\end{array}$ & $\begin{array}{l}\text { Accounting, Auditing } \\
\text { and Accountability } \\
\text { Journal }\end{array}$ & $\begin{array}{c}10.1108 / 095135 \\
70610709872\end{array}$ & 291 & - & 765 \\
\hline 9 & $\begin{array}{l}\text { Assurance statement practice in } \\
\text { environmental, social and } \\
\text { sustainability reporting: } \\
\text { A critical evaluation }\end{array}$ & $\begin{array}{l}\text { (O’Dwyer \& } \\
\text { Owen, 2005) } \\
\text { O'Dwyer B., } \\
\text { Owen D.L. }\end{array}$ & $\begin{array}{l}\text { British Accounting } \\
\text { Review }\end{array}$ & $\begin{array}{c}\text { 10.1016/j.bar.2005. } \\
01.005\end{array}$ & 273 & - & 622 \\
\hline $\begin{array}{l}1 \\
0\end{array}$ & $\begin{array}{l}\text { Sustainability accounting and } \\
\text { reporting: Fad or trend? }\end{array}$ & $\begin{array}{l}\text { (Burritt \& } \\
\text { Schaltegger, } \\
\text { 2010) } \\
\text { Burritt R.L., } \\
\text { Schaltegger S. }\end{array}$ & $\begin{array}{l}\text { Accountin, Auditing } \\
\& \\
\text { Accountability } \\
\text { Journal }\end{array}$ & $\begin{array}{c}10.1108 / 095135710 \\
11080144\end{array}$ & 266 & 228 & 615 \\
\hline
\end{tabular}


Figure 7 shows the document co-citation network generated by CiteSpace, showing the co-citation connection between these documents and the weight of the article. In order to generate Figure 7, we using the following parameters: (1) 8 years per interval from 1989 to 2019; (2) term source = title/abstract/author/keywords/keywords plus; (3) node type = reference; (4) pruning = pathfinder / pruning sliced networks; (5) select criteria is g-index factor $k=25$; (6) look back years $=8$; (7) link retaining factor $=3$. To improve readability, the label of the threshold is set to 20 . The frequency of citations determines the size of tags and nodes. The larger the label of a node, the more times it is referenced. The colour of the node indicates the age of the cited document.

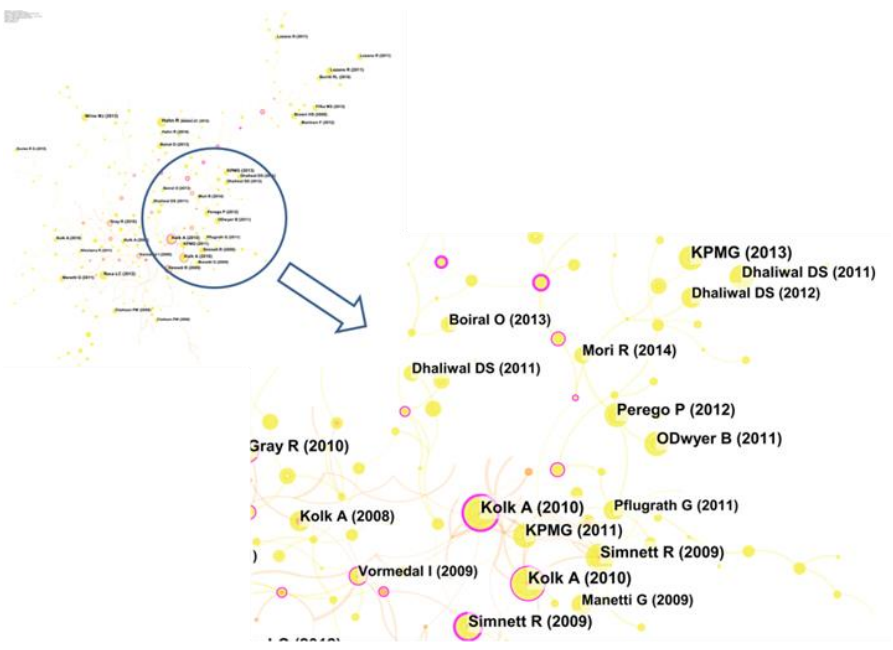

Figure 7. Co-citation network (1989-2019)

Table 6 present the detailed information of the co-citing literature network. We can see that the network has a total of 465 nodes and 556 links, of which 957 are located in 20132019 . At the same time, we also found that the vast majority of links $(13,462)$ were in 2013 2019. This shows that the sustainability report research has just recently received more and more attention.

Table 6. Cited references network

\begin{tabular}{|c|c|c|c|}
\hline Year & Nodes & Exposed Links & Total Links \\
\hline $1989-1996$ & 27 & 81 & 129 \\
\hline $1997-2004$ & 26 & 42 & 42 \\
\hline $2005-2012$ & 116 & 348 & 1,222 \\
\hline $2013-2019$ & 319 & 957 & 13,462 \\
\hline
\end{tabular}

\subsection{Subject areas / Categories}

All journals are marked in databases as belonging to one or several subject areas (Scopus) or categories (WoS). This section analyzes subject areas/categories of the sustainability report research. The subject of the survey article can enable us to understand which areas of research are related to the sustainability report research. The parameters set 
in CiteSpace are: (1) 1 years per interval from 1989 to 2019; (2) node type=category. Table 7 shows the top 10 topics with the largest number of documents.

Table 6. Main categories of sustainability reporting

\begin{tabular}{|c|l|c|}
\hline Rank & Category & Freq \\
\hline 1 & Business \& Economics & 342 \\
\hline 2 & Environmental Sciences \& Ecology & 217 \\
\hline 3 & Management & 155 \\
\hline 4 & Business & 150 \\
\hline 5 & Science \& Technology - Other Topics & 144 \\
\hline 6 & Green \& Sustainable Science \& Technology & 136 \\
\hline 7 & Environmental Studies & 134 \\
\hline 8 & Environmental Sciences & 120 \\
\hline 9 & Business, Finance & 103 \\
\hline 10 & Engineering & 82 \\
\hline
\end{tabular}

If similar categories are combined, we can find that Business, Economics, Management and Finance (Freq $=750$ ) is ranked first, and Environmental and Ecology (freq=607) is ranked second, and Science, Technology and Engineering closes the top three (freq=226). Investigating keywords can give us a complete overview of the research hotspots in this research field. We set the parameters in CiteSpace as: (1) 8 years per interval from 1989 to 2019; (2) term source = title/abstract/author/keywords/keywords plus; (3) node type = term/keyword; (4) pruning = pathfinder / pruning sliced networks / pruning the merged network; (5) select criteria is $g$-index factor $\mathrm{k}=15$; (6) look back years $=8$; (7) link retaining factor $=3$. Set label threshold $=8$, font size $=$ in the control panel 6 , node size $=60$. Adjust the position of the node appropriately, we get the keyword clustering graph (Figure 8).

Figure 8. Keyword co-occurrence diagram

Based on Figure 8, keyword clustering is performed in CiteSpace to obtain the keyword clustering map shown in the figure below (Figure 9). 


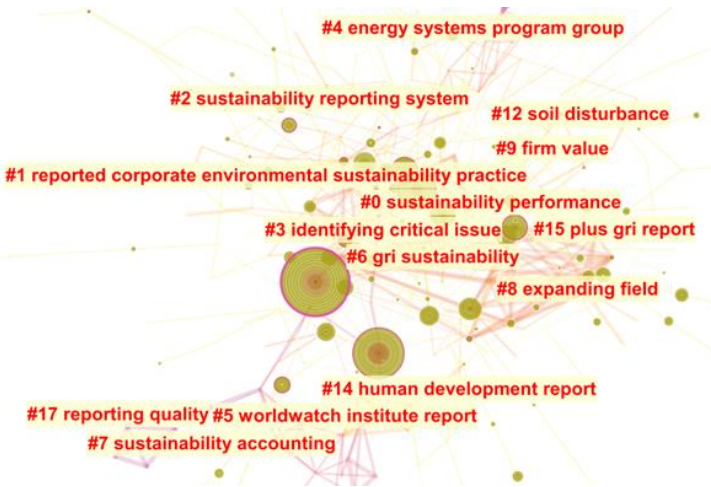

Figure 9. Keyword cluster map (1981-2019)

\subsection{Analysis of bursting keywords}

The burst keyword analysis reveals the research hotspots that have suddenly appeared in a research field for a while, show the appearance and duration of hot topics, and grasp the development path. We set the parameters in CiteSpace as follows: (1) 1 years per interval from 1989 to 2019; (2) term source = title/abstract/author/keywords/keywords plus; (3) node type = term/keyword; (4) pruning $=$ pathfinder / pruning sliced networks; (5) select criteria is g-index factor $\mathrm{k}=25$; (6) look back years $=8$; (7) link retaining factor $=3$. After running the analysis, pushing in the CiteSpace control panel "Burstness" we got the burst keyword map shown in Table 7:

Table 7. Top 21 Keywords with the Strongest Citation Bursts

\begin{tabular}{|l|c|c|c|c|c|}
\hline Keywords & Year & Strength & Begin & End & \\
\hline Environmental Impact & 1981 & 4.211 & 1995 & 2010 & \\
\hline Health & 1981 & 4.0076 & 1995 & 2011 & \\
\hline Article & 1981 & 9.9098 & 1996 & 2012 & \\
\hline Sustainable Development & 1981 & 15.9099 & 2000 & 2011 & \\
\hline Eurasia & 1981 & 5.5138 & 2005 & 2009 & \\
\hline North America & 1981 & 5.2265 & 2005 & 2007 & \\
\hline Europe & 1981 & 6.3395 & 2005 & 2009 & \\
\hline Financial Reporting & 1981 & 4.7369 & 2007 & 2013 & \\
\hline Corporate Sustainability & 1981 & 5.9793 & 2009 & 2016 & \\
\hline Human & 1981 & 5.7595 & 2010 & 2012 & \\
\hline Industry & 1981 & 5.5295 & 2010 & 2013 & \\
\hline Institutional Theory & 1981 & 4.91 & 2010 & 2012 & \\
\hline Report & 1981 & 5.0256 & 2010 & 2014 & \\
\hline Sustainability Indicator & 1981 & 4.1684 & 2011 & 2015 & \\
\hline Communication & 1981 & 3.7948 & 2012 & 2014 & \\
\hline Stakeholder & 1981 & 4.9566 & 2013 & 2014 & \\
\hline Sustainability Assessment & 1981 & 4.5157 & 2014 & 2016 & \\
\hline Standard & 1981 & 4.1585 & 2015 & 2016 & \\
\hline Stakeholder Theory & 1981 & 5.1846 & 2015 & 2017 & \\
\hline Quality & 1981 & 4.0916 & 2016 & 2019 & \\
\hline CSR & 1981 & 4.8793 & 2017 & 2019 & \\
\hline
\end{tabular}

From 1995 to 2012, three keywords are lasting more than 15 years, namely environmental impact, health and article. From 2000 to 2011, the burst keyword "sustainable 
development" was the keyword with the highest burst intensity. These 4 keywords are the most popular research topics in the first 10 years of the 21 st century. It should also be noted how research priorities have changed. From 2005 to 2009, keywords based on region, Eurasia, North America, and Europe have become hot spots. Beginning in 2007, the burst of research has shifted from macro to the mesolevel as more and more studies began to appear occupied with companies as opposed to regions. A notable feature of that period is also that burst keywords began to be related to financial reports, companies, and industries, and this trend has continued to the present.

What happened from 2011 in remarkable as it manifests the reaching of maturity of the field of sustainability reporting. Notable feature since 2011 is that at least one new burst keyword has appeared every year, which shows that the research of sustainability report has been carried out in multiple sub-fields coexisting and developing in parallel.

\subsection{Future research directions}

It is our perception that any research based on past data cannot be complete if it does not allow us to glimpse into the future. When looking for future research directions, we summarized the articles published in 2019 to identify innovative research opportunities. We generated a keyword co-occurrence map based on the keywords of articles published in 2019 and then generated a cluster map on this basis. We used the following parameters: (1) 1 years per slice in 2019; (2) term source = title/abstract/author/keywords $/$ keywords plus; (3) node type = keyword; (4) pruning = pathfinder, pruning sliced networks; (5) select criteria is $g$-index factor $\mathrm{k}=25$; (6) look back years $=8$; (7) link retaining factor $=3$. After running CiteSpace, we got 159 nodes, 203 links, after finding the clusters, we got 10 clusters with modularity $\mathrm{Q}=0.8117$, Mean Silhouette $=0.7686$. The scores of modularity $\mathrm{Q}$ and mean silhouette range from 0 to 1 . The larger the modularity $Q$ value, the more structured the network. Reasonable, the larger the value of mean silhouette, the higher the credibility of the classification. To make the network clear, we use the "Filter out small clusters" function to hide the smaller clusters.

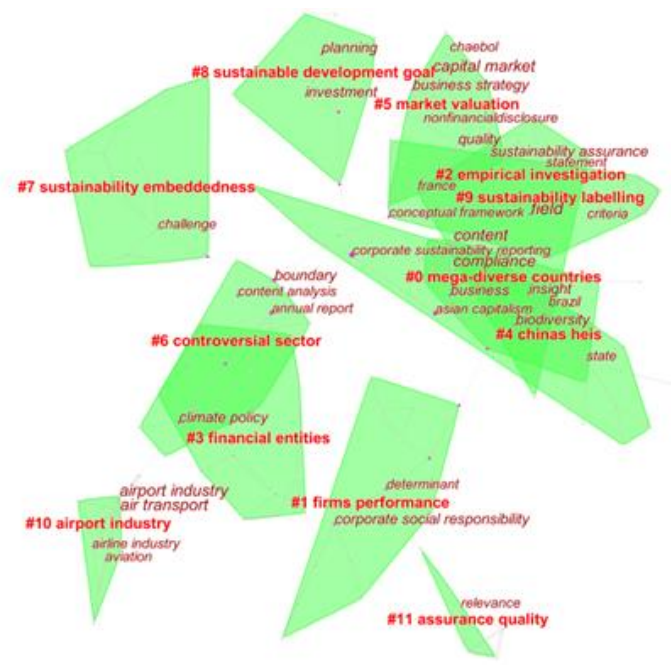

Figure 10. Sustainability report research keyword cluster map in 2019 
Table 9 shows the keywords that appear most frequently, that is, the top 10 most relevant clusters. The marking technique is the log-likelihood ratio (LLR) (Chen et.al, 2010). The cluster numbers are arranged in descending order of frequency.

Table 9. Future research directions

\begin{tabular}{|c|c|l|}
\hline$\#$ & Freq & keyword \\
\hline 1 & 127 & Sustainability Reporting \\
\hline 2 & 44 & Corporate Social Responsibility \\
\hline 3 & 35 & Sustainable Development \\
\hline 4 & 31 & Disclosure \\
\hline 5 & 22 & Performance \\
\hline 6 & 21 & Governance \\
\hline 7 & 21 & Management \\
\hline 8 & 19 & Global Reporting Initiative \\
\hline 9 & 18 & GRI \\
\hline 10 & 17 & Determinant \\
\hline
\end{tabular}

Based on the bibliometric analysis we assume that the keywords listed in Table 9 are the 10 keywords with the highest frequency in articles published in 2019, and they likely will also be the main research directions in the near future.

\section{Discussions and Conclusions}

This paper aims to map the literature on sustainability reporting by refining its research fields and detecting trends. To reach our aim we conducted a bibliometric analysis using CiteSpace software by applying evaluative and relational techniques (Baraibar-Diez et al., 2020; Fabregat-Aibar et al., 2019). We strive to provide researchers with a quantified and visualized snapshot of the domain of sustainability reporting covering all the publication available in the leading databases Scopus and Web of Science Core Collection from 1981 up to 2020. The scope of our study is 928 articles published in 480 different journals in Scopus and 698 articles published in 374 different journals in Web of Science Core Collection.

The number of articles related to sustainability reporting in Scopus $(n=928)$ is greater than that in WoS ( $\mathrm{n}=698)$. There are a total of 1,626 articles in the search results, of which 451 are repeated in the Scopus and WoS databases. Although there are many crossovers, many articles are in only one database: Scopus has 477 of those articles and WoS - 105 articles. In terms of publications output, we marked three significant years: (1) 1981 - the first appearance of the publication related to the subject matter; (2) 2004 - since when the number of related articles published per year has exceeded 10 and (3) 2015 - when the number of articles per year has exceeded 100 and continued to hover around this number since after it.

In terms of a citation we have marked 2000 and 2015 as watershed years: before 2000, only articles published in 1991, 1995, and 1997 had a large number of citations; from 2001 to 2015, the number of citations increased rapidly, and reached a peak in 2015; the number of citations of articles published after 2015 has gradually decreased (what is a natural 
process as to accrue citation some time should past).

Assessed only after publications the United States, Australia, the United Kingdom, Germany, and Spain are the top five countries with the most publications in the Scopus, whereas, in the WoS database, the United States, the United Kingdom, Australia, Spain and Germany are the countries with the most publications. But when we add betweenness centrality to the equation in the top five countries in Scopus Canada replaces Spain. Consideration of betweenness centrality shakes the top five countries in WoS as only the United Kingdom, the United States and Germany hold its places while Australia, Spain vacate their places for the Netherlands and Italy respectively.

The most prolific journals in the study and also the most-cited journal (in absolute terms as well as on per article basis) are Journal of Cleaner Production, Business Strategy and the Environment, Journal of Business Ethics.

We found that 393 authors are participating in 928 articles in the Scopus database, and 460 authors participating in 698 articles in the WoS database. The top three authors in Scopus are Amran A. (Universiti Sains Malaysia), James M.L. (California State University), Uyar A. (La Rochelle Business School) in WoS - Fernandez-Feijoo B. (Universidade de Vigo), Boiral O. (Université Laval) and Rezaee Zabihollah (Univ Memphis). In two databases, only 3 of the top 10 authors have overlapped (Fernandez-Feijoo B. from Universidade de Vigo, Uyar A. from La Rochelle Business School, Boiral O. affiliated with Université Laval). Our study has also identified the top 10 articles cited, therefrom Scopus contains all 10 articles, and only 4 articles are included in the WoS.

Co-citation connection between these documents allowed us to identify the network of a total of 465 nodes and 556 links, of which 957 are located in 2013-2019. From these findings, we infer that sustainability reporting research has just recently received more and more attention and gained traction in the literature.

All journals are marked in databases as belonging to one or several subject areas (Scopus) or categories (WoS). The conducted analysis revealed (if similar categories in two databases are combined) that Business, Economics, Management and Finance is ranked first (Freq=750), Environmental and Ecology - second (freq=607), and closes the top three Science, Technology and Engineering (freq=226).

The burst keyword analysis revealed how research priorities have changed with the lapse of time. From 2005 to 2009, keywords based on regions, like Eurasia, North America, and Europe dominated, whereas starting in 2007, the burst of research has shifted from macro to the mesolevel as more and more studies began to appear occupied with companies as opposed to regions.

Another key watershed moment (kind of a bifurcation point) we identified is 2011 as it, we believe manifests the reaching of maturity by the field of sustainability reporting. Since 2011 there are at least one new bursting keyword has appeared every year, which shows that the research of sustainability report has been carried out in multiple sub-fields coexisting and developing in parallel.

A keyword co-occurrence map based on the keywords of articles published in 2019 and log-likelihood ratio marking technique allowed us to identify the keywords listed with the highest frequency and they likely will also be the main research directions shortly (in descending order of frequency): sustainability reporting, corporate social responsibility, sustainable development, disclosure. 
The main limitations of this paper must be mentioned. Those limitations has its roots in the methodological choices made by authors. First, we analyze articles in English only. This choice is obvious, as the majority of contemporary articles are written in this language, but articles in other languages are also becoming increasingly popular, especially in the WoS, which has indexes in Chinese, Russian and Spanish. We believe that research into these articles may open up some new perspectives. The second limitation may be linked to the bibliometric analysis which could contain deeply rooted bias as it heavily focuses on the most cited works. In practice though, this could have another conflicting explication because as a rule "the most cited references tend to be the oldest ones, thereby generating a temporal bias" (Lopes \& de Carvalho, 2018, p. 296).

This shortcoming can be mitigated in future research which would also include research papers written in a language other than English. Besides, other types of publications (book chapters and proceedings papers) and other high-quality studies in these two databases capable to deliver additional valuable information that opens up an additional view of the field. It would also be useful to contrast the findings of such studies with those presented in this paper.

\section{References}

Araújo, A. G., Pereira Carneiro, A. M., \& Palha, R. P. (2020). Sustainable construction management: A systematic review of the literature with meta-analysis. Journal of Cleaner Production, 256, 120350. https://doi.org/10.1016/j.jclepro.2020.120350

Baraibar-Diez, E., Luna, M., Odriozola, M. D., \& Llorente, I. (2020). Mapping Social Impact: A Bibliometric Analysis. Sustainability, 12(22), 9389. https://doi.org/10.3390/su12229389

Barton, N. W., Furbish, F. S., Murray, G. J., Garfield, M., \& Brady, R. O. (1990). Therapeutic response to intravenous infusions of glucocerebrosidase in a patient with Gaucher disease. Proceedings of the National Academy of Sciences, 87(5), 1913-1916. https://doi.org/10.1073/pnas.87.5.1913

Bepari, M. K., \& Mollik, A. T. (2016). Stakeholders' interest in sustainability assurance process. Managerial Auditing Journal, 31(6/7), 655-687. https://doi.org/10.1108/MAJ-06-2015-1208

Boiral, O. (2013). Sustainability reports as simulacra? A counter-account of A and A+ GRI reports. Accounting, Auditing \& Accountability Journal, 26(7), 1036-1071. https://doi.org/10.1108/AAAJ-04-2012-00998

Burritt, R. L., \& Schaltegger, S. (2010). Sustainability accounting and reporting: fad or trend? Accounting, Auditing \& Accountability Journal, 23(7), 829-846. https://doi.org/10.1108/09513571011080144

Canning, M., O’Dwyer, B., \& Georgakopoulos, G. (2019). Processes of auditability in sustainability assurance - the case of materiality construction. Accounting and Business Research, 49(1), 1-27. https://doi.org/10.1080/00014788.2018.1442208

Chen, C. (2018). Eugene Garfield's scholarly impact: a scientometric review. Scientometrics, 114(2), 489-516. https://doi.org/10.1007/s11192-017-2594-5

Chen, D., Liu, Z., Luo, Z., Webber, M., \& Chen, J. (2016). Bibliometric and visualized analysis of energy research. Ecological Engineering, 90, 285-293. https://doi.org/10.1016/j.ecoleng.2016.01.026

Chen, C. (2004). Searching for intellectual turning points: Progressive knowledge domain visualization. Proceedings of the National Academy of Sciences, 101(Supplement 1), 5303-5310. https://doi.org/10.1073/pnas.0307513100

Daub, C.-H. (2007). Assessing the quality of sustainability reporting: an alternative methodological approach. Journal of Cleaner Production, 15(1), 75-85. https://doi.org/10.1016/j.jclepro.2005.08.013

de Bellis, N. (2014). History and Evolution of (Biblio)Metrics. In Beyond Bibliometrics. The MIT Press. https://doi.org/10.7551/mitpress/9445.003.0004

Dienes, D., Sassen, R., \& Fischer, J. (2016). What are the drivers of sustainability reporting? A systematic review. Sustainability Accounting, Management and Policy Journal, 7(2), 154-189. https://doi.org/10.1108/SAMPJ-08-2014-0050 
Dumay, J. (2019). Sustainability accounting and integrated reporting. Social and Environmental Accountability Journal, 39(1), 70-71. https://doi.org/10.1080/0969160X.2018.1515160

Elsevier. (2020). Scopus. Expertly curated abstract \& citation database. https://www.elsevier.com/solutions/scopus?dgcid=RN_AGCM_Sourced_300005030

Fabregat-Aibar, L., Barberà-Mariné, M. G., Terceño, A., \& Pié, L. (2019). A Bibliometric and Visualization Analysis of Socially Responsible Funds. Sustainability, 11(9), 2526. https://doi.org/10.3390/su11092526

Farooq, M. B., \& de Villiers, C. (2017). The market for sustainability assurance services. Pacific Accounting Review, 29(1), 79-106. https://doi.org/10.1108/PAR-10-2016-0093

Farooq, M. B., \& de Villiers, C. (2019a). Sustainability Assurance: Who Are the Assurance Providers and What Do They Do? In Challenges in Managing Sustainable Business (pp. 137-154). Springer International Publishing. https://doi.org/10.1007/978-3-319-93266-8_6

Farooq, M. B., \& de Villiers, C. (2019b). The shaping of sustainability assurance through the competition between accounting and non-accounting providers. Accounting, Auditing \& Accountability Journal, 32(1), 307-336. https://doi.org/10.1108/AAAJ-10-2016-2756

Fusco, F., \& Ricci, P. (2019). What is the stock of the situation? A bibliometric analysis on social and environmental accounting research in public sector. International Journal of Public Sector Management, 32(1), 21-41. https://doi.org/10.1108/IJPSM-05-2017-0134

Gao, H., Ding, X.-H., \& Wu, S. (2020). Exploring the domain of open innovation: Bibliometric and content analyses. Journal of Cleaner Production, 275, 122580. https://doi.org/10.1016/j.jclepro.2020.122580

Gray, R. (2006). Social, environmental and sustainability reporting and organisational value creation? Accounting, Auditing \& Accountability Journal, 19(6), 793-819. https://doi.org/10.1108/09513570610709872

Gulluscio, C., Puntillo, P., Luciani, V., \& Huisingh, D. (2020). Climate Change Accounting and Reporting: A Systematic Literature Review. Sustainability, 12(13), 5455. https://doi.org/10.3390/su12135455

Gusenbauer, M. (2019). Google Scholar to overshadow them all? Comparing the sizes of 12 academic search engines and bibliographic databases. Scientometrics, 118(1), 177-214. https://doi.org/10.1007/s11192-018-2958-5

Hahn, R., \& Kühnen, M. (2013). Determinants of sustainability reporting: a review of results, trends, theory, and opportunities in an expanding field of research. Journal of Cleaner Production, 59, 5-21. https://doi.org/10.1016/j.jclepro.2013.07.005

Hahn, R., \& Lülfs, R. (2014). Legitimizing Negative Aspects in GRI-Oriented Sustainability Reporting: A Qualitative Analysis of Corporate Disclosure Strategies. Journal of Business Ethics, 123(3), 401-420. https://doi.org/10.1007/s10551-013-1801-4

Herremans, I. M., Nazari, J. A., \& Mahmoudian, F. (2016). Stakeholder Relationships, Engagement, and Sustainability Reporting. Journal of Business Ethics, 138(3), 417-435. https://doi.org/10.1007/s10551015-2634-0

Hummel, K., Schlick, C., \& Fifka, M. (2019). The Role of Sustainability Performance and Accounting Assurors in Sustainability Assurance Engagements. Journal of Business Ethics, 154(3), 733-757. https://doi.org/10.1007/s10551-016-3410-5

Kolk, A. (2003). Trends in sustainability reporting by the Fortune Global 250. Business Strategy and the Environment, 12(5), 279-291. https://doi.org/10.1002/bse.370

Kolk, A. (2008). Sustainability, accountability and corporate governance: exploring multinationals' reporting practices. Business Strategy and the Environment, 17(1), 1-15. https://doi.org/10.1002/bse.511

KPMG. (2017). The road abead. The KPMG Survey of Corporate Responsibility Reporting 2017. https://assets.kpmg/content/dam/kpmg/be/pdf/2017/kpmg-survey-of-corporateresponsibility-reporting-2017.pdf

La Torre, M., Sabelfeld, S., Blomkvist, M., \& Dumay, J. (2020). Rebuilding trust: sustainability and nonfinancial reporting and the European Union regulation. Meditari Accountancy Research, 28(5), 701-725. https://doi.org/10.1108/MEDAR-06-2020-0914

Lopes, A. P. V. B. V., \& de Carvalho, M. M. (2018). Evolution of the open innovation paradigm: Towards a contingent conceptual model. Technological Forecasting and Social Change, 132, 284-298. https://doi.org/10.1016/j.techfore.2018.02.014

Lubchenco, J., Olson, A. M., Brubaker, L. B., Carpenter, S. R., Holland, M. M., Hubbell, S. P., Levin, S. A., MacMahon, J. A., Matson, P. A., Melillo, J. M., Mooney, H. A., Peterson, C. H., Pulliam, H. R., Real, L. A., Regal, P. J., \& Risser, P. G. (1991). The Sustainable Biosphere Initiative: An Ecological Research Agenda: A Report from the Ecological Society of America. Ecology, 72(2), 371-412. https://doi.org/10.2307/2937183 
Michelon, G., Pilonato, S., \& Ricceri, F. (2015). CSR reporting practices and the quality of disclosure: An empirical analysis. Critical Perspectives on Accounting, 33, 59-78. https://doi.org/10.1016/j.cpa.2014.10.003

Milne, M. J., \& Gray, R. (2013). W(h)ither Ecology? The Triple Bottom Line, the Global Reporting Initiative, and Corporate Sustainability Reporting. Journal of Business Ethics, 118(1), 13-29. https://doi.org/10.1007/s10551-012-1543-8

Mingers, J., \& Leydesdorff, L. (2015). A Review of Theory and Practice in Scientometrics. https://doi.org/10.1016/j.ejor.2015.04.002

Mio, C., Fasan, M., \& Costantini, A. (2020). Materiality in integrated and sustainability reporting: A paradigm shift? Business Strategy and the Environment, 29(1), 306-320. https://doi.org/10.1002/bse.2390

O’Dwyer, B., \& Owen, D. L. (2005). Assurance statement practice in environmental, social and sustainability reporting: a critical evaluation. The British Accounting Review, 37(2), 205-229. https://doi.org/10.1016/j.bar.2005.01.005

Pizzi, S., Caputo, A., Corvino, A., \& Venturelli, A. (2020). Management research and the UN sustainable development goals (SDGs): A bibliometric investigation and systematic review. Journal of Cleaner Production, 276, 124033. https://doi.org/10.1016/j.jclepro.2020.124033

Rhianon Edgley, C., Jones, M. J., \& Solomon, J. F. (2010). Stakeholder inclusivity in social and environmental report assurance. Accounting, Auditing \& Accountability Journal, 23(4), 532-557. https://doi.org/10.1108/09513571011041615

Rodrigues, M., \& Mendes, L. (2018). Mapping of the literature on social responsibility in the mining industry: A systematic literature review. Journal of Cleaner Production, 181, 88-101. https://doi.org/10.1016/j.jclepro.2018.01.163

Rossi, A., \& Tarquinio, L. (2017). An analysis of sustainability report assurance statements. Managerial Auditing Journal, 32(6), 578-602. https://doi.org/10.1108/MAJ-07-2016-1408

Rousseau, R., Egghe, L., \& Guns, R. (2018). Becoming metric-wise: A bibliometric guide for researchers. Chandos Publishing.

Simnett, R., Vanstraelen, A., \& Chua, W. F. (2009). Assurance on Sustainability Reports: An International Comparison. The Accounting Review, 84(3), 937-967. https://doi.org/10.2308/accr.2009.84.3.937

Tjahjadi, B., Harymawan, I., \& Warsidi, N. S. (2020). Implementation of integrated reporting: a cross-countries' study. Entrepreneurship and Sustainability Issues, 7(4), 2832-2850. https://doi.org/10.9770/jesi.2020.7.4(17)

Torelli, R., Balluchi, F., \& Furlotti, K. (2020). The materiality assessment and stakeholder engagement: A content analysis of sustainability reports. Corporate Social Responsibility and Environmental Management, 27(2), 470-484. https://doi.org/10.1002/csr.1813

van Staden, C. J., \& Hooks, J. (2007). A comprehensive comparison of corporate environmental reporting and responsiveness. The British Accounting Review, 39(3), 197-210. https://doi.org/10.1016/j.bar.2007.05.004 